\title{
UNRAVELLING THE HYDROLYSIS PATHWAY OF DIORGANOTIN DIHALIDES TOWARDS MOLECULAR DIORGANOTIN OXIDES
}

\author{
Jens Beckmann', Dainis Dakternieks², Andrew Duthie ${ }^{2}$, \\ Klaus Jurkschat ${ }^{1}$, and Markus Schürmann ${ }^{1}$ \\ ${ }^{1}$ Lehrstuhl fur Anorganische Chemie II der Universitat Dortmund, 44221 Dortmund, Germany \\ - Centre for Chiral and Molecular Technologies, Deakin University, Geelong 3217, Australia
}

\begin{abstract}
The synthesis and controlled hydrolysis is reported of $\left(\mathrm{Me}_{3} \mathrm{SiCH}_{2}\right)_{2} \mathrm{SnX}_{2}(\mathrm{X}=\mathrm{Cl}(\mathbf{1}), \mathrm{Br}(2))$, which provided the water adduct $\left(\mathrm{Me}_{3} \mathrm{SiCH}_{2}\right)_{2} \mathrm{SnCl}_{2} \cdot \mathrm{H}_{2} \mathrm{O}(1 \mathrm{a})$, and the symmetrically substituted dimeric tetraorganodistannoxanes $\left[\mathrm{R}_{2}(\mathrm{X}) \mathrm{SnOSn}(\mathrm{X}) \mathrm{R}_{2}\right]_{2}\left(\mathrm{X}=\mathrm{Cl}(3), \mathrm{OH}(5) ; \mathrm{R}=\mathrm{CH}_{2} \mathrm{SiMe}_{3}\right)$. The asymmetrically substituted dimeric tetraorganodistannoxanes $\left[\mathrm{R}_{2}(\mathrm{HO}) \mathrm{SnOSn}(\mathrm{Cl}) \mathrm{R}_{2}\right]_{2}\left(4, \mathrm{R}=\mathrm{CH}_{2} \mathrm{SiMe}_{3}\right)$ was prepared by a redistribution reaction of 3 and 5 . Dehydration of 5 using activated molecular sieve afforded the trimeric diorganotin oxide, $\left[\left(\mathrm{Me}_{3} \mathrm{SiCH}_{2}\right)_{2} \mathrm{SnO}\right]_{3}(6)$. Compounds 1a, 3, 5 and 6 were investigated by $\mathrm{X}$-ray diffraction.
\end{abstract}

\section{Introduction}

Depending on the identity of the substituents $\mathrm{R}$ and $\mathrm{X}$ and the reaction conditions applied, the hydrolysis of diotganotin dihalides $(\mathrm{R}=$ alkyl, aryl; $\mathrm{X}=\mathrm{Cl}, \mathrm{Br})$ gives rise to the formation of different molecular products, such as dimeric tetraorganodistannoxanes, $\left[R_{2}(X) \operatorname{SnOSn}(Y) R_{2}\right]_{2}$, dimeric diorganotin hydroxide halides, $\left[\mathrm{R}_{2} \mathrm{Sn}(\mathrm{OH}) \mathrm{X}\right]_{2}$, or trimeric diorganotin oxides, $\left(\mathrm{R}_{2} \mathrm{SnO}\right)_{3}(\mathrm{R}=$ alkyl, aryl; $\mathrm{X}, \mathrm{Y}=\mathrm{Cl}, \mathrm{Br}$, $\mathrm{OH}$ [ [1-10]. However, so far no case is known, in which a full series of hydrolysis products containing the same organic substituents, has been described. Regarding this matter, we report here preliminary results on the hydrolysis of $\left(\mathrm{Me}_{3} \mathrm{SiCH}_{2}\right)_{2} \mathrm{SnX}_{2}(\mathrm{X}=\mathrm{Cl}, \mathrm{Br})$ including four fully characterized new compounds, $\mathrm{R}_{2} \mathrm{SnCl}_{2} \cdot \mathrm{H}_{2} \mathrm{O},\left[\mathrm{R}_{2}(\mathrm{Cl}) \mathrm{SnOSn}(\mathrm{Cl}) \mathrm{R}_{2}\right]_{2},\left[\mathrm{R}_{2}(\mathrm{HO}) \operatorname{SnOSn}(\mathrm{OH}) \mathrm{R}_{2}\right]_{2},\left(\mathrm{R}_{2} \mathrm{SnO}\right)_{3}$ with the same organic group, $\mathrm{R}$ $=\mathrm{CH}_{2} \mathrm{SiMe}_{3}$ [11]. This series is supplemented by another hydrolysis product, $\left[\mathrm{R}_{2}(\mathrm{HO}) \operatorname{SnOSn}(\mathrm{Cl}) \mathrm{R}_{2}\right]_{2}(\mathrm{R}=$ $\mathrm{CH}_{2} \mathrm{SiMe}_{3}$ ), for which the molecular structure was previously published by Puff et al. [6].

\section{Results and discussion}

The synthesis of the starting materials $\left(\mathrm{Me}_{3} \mathrm{SiCH}_{2}\right)_{2} \mathrm{SnX} \mathrm{X}_{2}(\mathrm{X}=\mathrm{Cl}(\mathbf{1}), \mathrm{Br}(2))$ was achieved by cleaving the phenyl groups in $\left(\mathrm{Me}_{3} \mathrm{SiCH}_{2}\right)_{2} \mathrm{SnPh}_{2}$ using hydrogen chloride or bromide, respectively (Eq. 1)

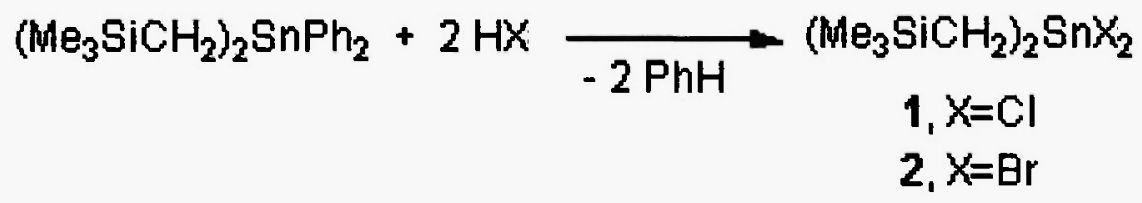

In the presence of moist air, $\left(\mathrm{Me}_{3} \mathrm{SiCH}_{2}\right)_{2} \mathrm{SnCl}_{2}$ (1) forms a water adduct, $\left(\mathrm{Me}_{3} \mathrm{SiCH}_{2}\right)_{2} \mathrm{SnCl}_{2} \cdot \mathrm{H}_{2} \mathrm{O}(\mathbf{1} \mathbf{a})$ which can be regarded as first hydrolysis product along the hydrolysis pathway to diorganotin oxides. In contrast, $\left(\mathrm{Me}_{3} \mathrm{SiCH}_{2}\right)_{2} \mathrm{SnBr}_{2}$ (2) forms no such water adduct. The molecular structure of $\left(\mathrm{Me}_{3} \mathrm{SiCH}_{2}\right)_{2} \mathrm{SnCl}_{2} \cdot \mathrm{H}_{2} \mathrm{O}(1 \mathrm{a})$ is shown in Figure 1 .

The reaction of $\left(\mathrm{Me}_{3} \mathrm{SiCH}_{2}\right)_{2} \mathrm{SnCl}_{2}$ (1) with water in the presence of the appropriate amount of triethylamine afforded the dimeric tetraorganodistannoxane $\left[\mathrm{R}_{2}(\mathrm{Cl}) \mathrm{SnOSn}(\mathrm{Cl}) \mathrm{R}_{2}\right]_{2}\left(3, \mathrm{R}=\mathrm{CH}_{2} \mathrm{SiMe}_{3}\right)(\mathrm{Eq}$. 2). 


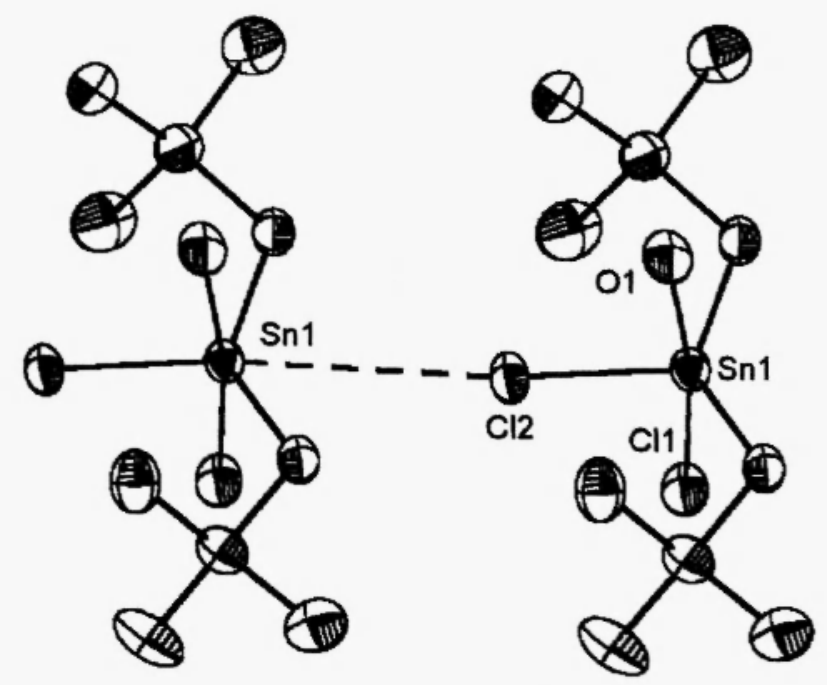

Figure 1. DIAMOND [12] presentation of $\left(\mathrm{Me}_{3} \mathrm{SiCH}_{2}\right)_{2} \mathrm{SnCl}_{2} \cdot \mathrm{H}_{2} \mathrm{O}$ (1a). Selected bond lengths:

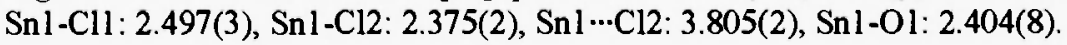

Notably, the hydrolysis of $\left(\mathrm{Me}_{3} \mathrm{SiCH}_{2}\right)_{2} \mathrm{SnCl}_{2}$ (1) with sodium hydroxide under different reaction conditions providing the dimeric tetraorganodistannoxane $\left[\mathrm{R}_{2}(\mathrm{Cl}) \mathrm{SnOSn}(\mathrm{OH}) \mathrm{R}_{2}\right]_{2}\left(4, \mathrm{R}=\mathrm{CH}_{2} \mathrm{SiMe}_{3}\right)$ ) was already reported by Puff et al. [6]. An alternative method for the preparation of 4 is given below. The molecular structure of $\left[\mathrm{R}_{2}(\mathrm{Cl}) \mathrm{SnOSn}(\mathrm{Cl}) \mathrm{R}_{2}\right]_{2}\left(3, \mathrm{R}=\mathrm{CH}_{2} \mathrm{SiMe}_{3}\right)$ is shown in Figure 2.

$$
4 \mathrm{R}_{2} \mathrm{SnCl}_{2} \frac{2 \mathrm{H}_{2} \mathrm{O}, 4 \mathrm{NEt}_{3}}{-4 \mathrm{HNEt}_{3} \mathrm{Cl}} \rightarrow \mathrm{CH}_{2} \mathrm{Sime}_{3}
$$

The hydrolysis of $\left(\mathrm{Me}_{3} \mathrm{SiCH}_{2}\right)_{2} \mathrm{SnBr}_{2}$ (2) with sodium hydroxide under reactions conditions comparable to those described by Puff et al. [6] for the preparation of $\left[\mathrm{R}_{2}(\mathrm{Cl}) \operatorname{SnOSn}(\mathrm{OH}) \mathrm{R}_{2}\right]_{2}(4, \mathrm{R}=$ $\left.\mathrm{CH}_{2} \mathrm{SiMe}_{3}\right)$ ) gave the dimeric tetraorganodistannoxane $\left[\mathrm{R}_{2}(\mathrm{HO}) \mathrm{SnOSn}(\mathrm{OH}) \mathrm{R}_{2}\right]_{2}\left(5, \mathrm{R}=\mathrm{CH}_{2} \mathrm{SiMe} 3\right)$ ) (Eq. 3), for which the molecular structure is presented in Figure 3.

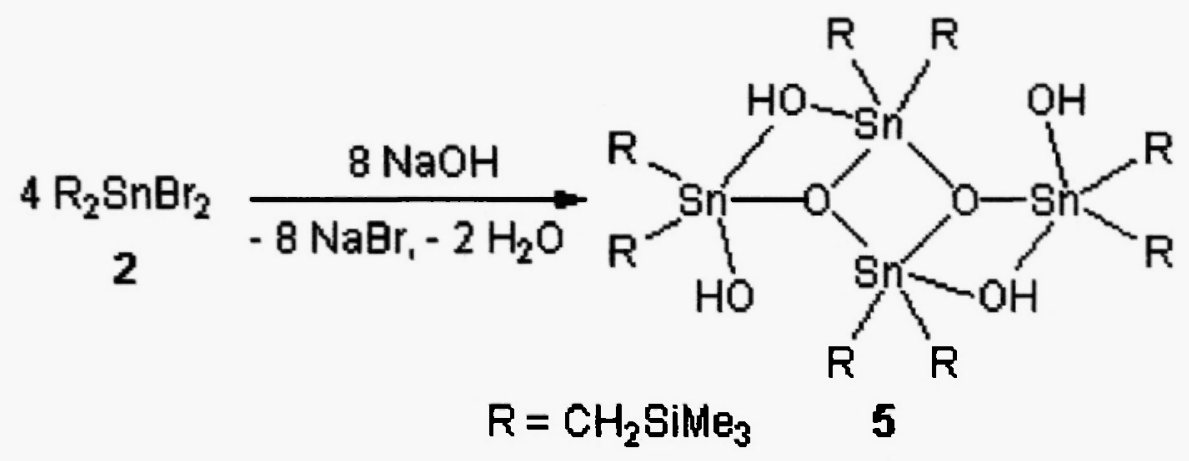




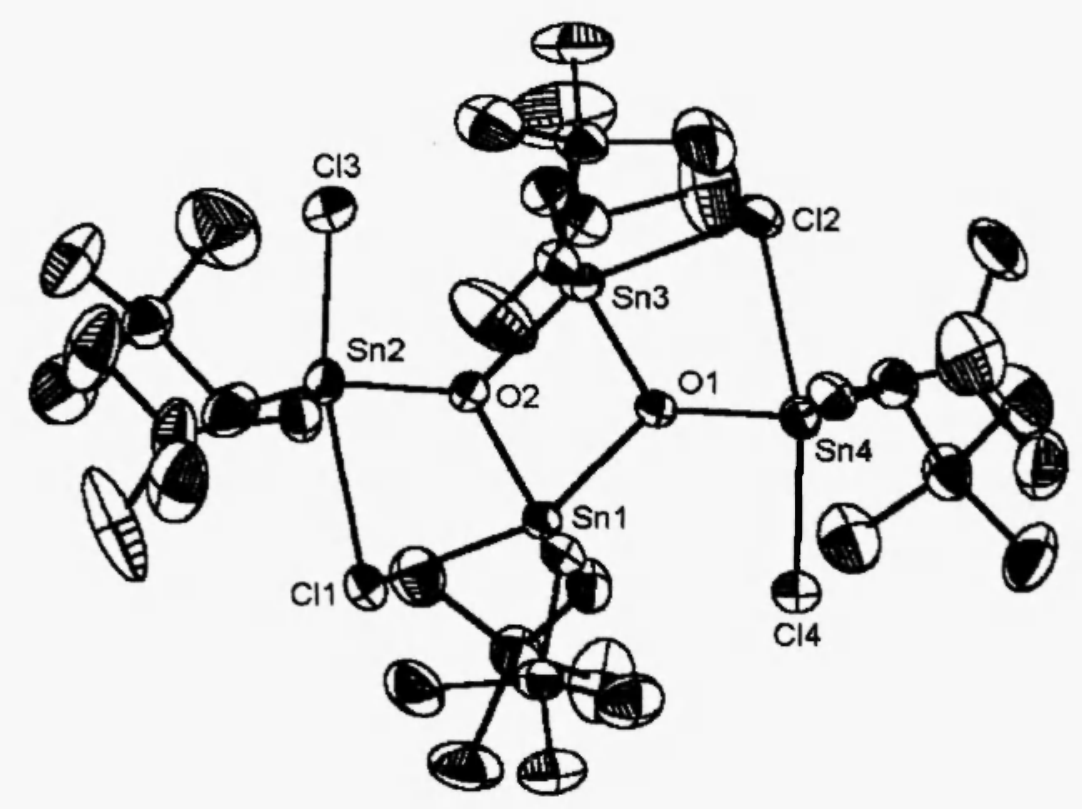

Figure 2. DIAMOND [12] presentation of $\left[\mathrm{R}_{2}(\mathrm{Cl}) \mathrm{SnOSn}(\mathrm{Cl}) \mathrm{R}_{2}\right]_{2}\left(3, \mathrm{R}=\mathrm{CH}_{2} \mathrm{SiMe}_{3}\right)$. Selected

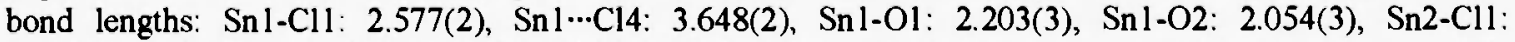


Sn3-O2: 2.191(3), Sn4-C12: 2.857(2), Sn4-Cl4: 2.414(2), Sn4-O1: 2.015(3).



Figure 3. DIAMOND [12] presentation of $\left[\mathrm{R}_{2}(\mathrm{HO}) \operatorname{SnOSn}(\mathrm{OH}) \mathrm{R}_{2}\right]_{2}\left(5, \mathrm{R}=\mathrm{CH}_{2} \mathrm{SiMe}_{3}\right)$. Selected

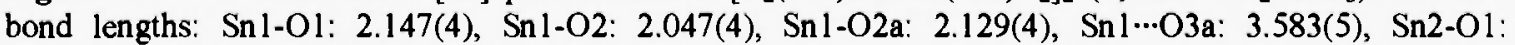
2.342(4), Sn2-O2: 2.019(4), Sn2-O3: 2.032(4). 
In solution, $\left.\left[\mathrm{R}_{2}(\mathrm{HO}) \operatorname{SnOSn}(\mathrm{OH}) \mathrm{R}_{2}\right]_{2}\left(5, \mathrm{R}=\mathrm{CH}_{2} \mathrm{SiMe}_{3}\right)\right)$ is in equilibrium with the molecular diorganotin oxide, $\left[\left(\mathrm{Me}_{3} \mathrm{SiCH}_{2}\right)_{2} \mathrm{SnO}_{3}(6)\right.$ and water (Eq. 4). Addition of activated molecular sieve shifts the equilibrium completely to $\left[\left(\mathrm{Me}_{3} \mathrm{SiCH}_{2}\right)_{2} \mathrm{SnO}_{3}(6)\right.$, which could be isolated and investigated by $\mathrm{X}$-ray diffraction. The molecular structure is depicted in Figure 4.

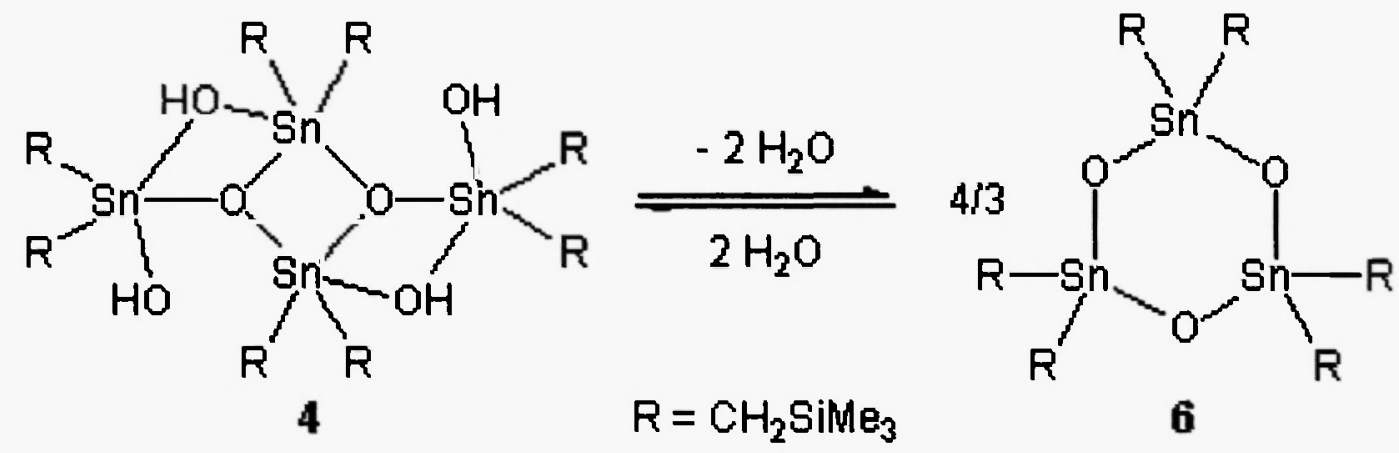

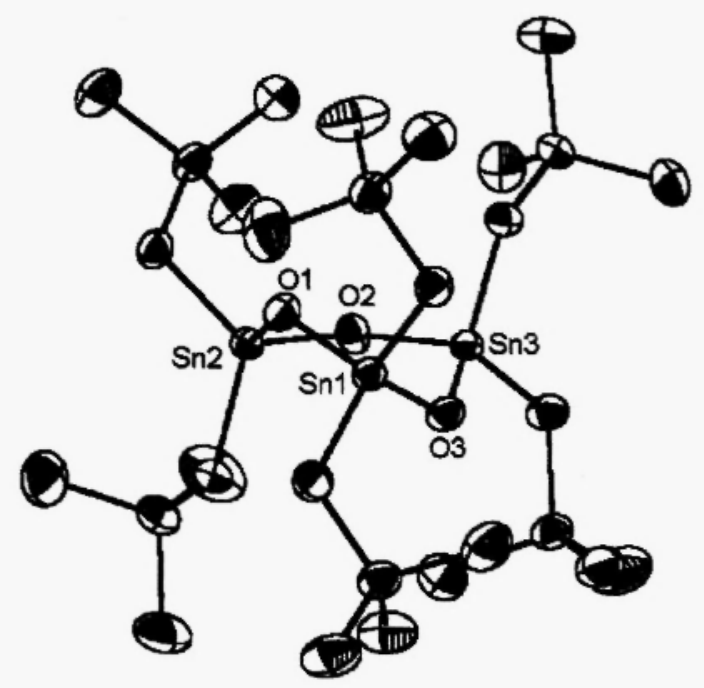

Figure 4. DIAMOND [12] presentation of $\left[\left(\mathrm{Me}_{3} \mathrm{SiCH}_{2}\right)_{2} \mathrm{SnO}_{3}(6)\right.$. Selected bond lengths: Snl-OI: 1.961(2), Sn1-03: 1.966(3), Sn2-O1: 1.966(3), Sn2-O2: 1.965(3), Sn3-O2: 1.962(3), Sn3-O3: 1.980(2).

Alternatively to the hydrolysis method reported by Puff et al. [6], $\left[\mathrm{R}_{2}(\mathrm{HO}) \operatorname{SnOSn}(\mathrm{Cl}) \mathrm{R}_{2}\right]_{2}(4, \mathrm{R}=$ $\mathrm{CH}_{2} \mathrm{SiMe}_{3}$ ) could prepared by a redistribution reaction of the symmetrically substituted dimeric tetraorganodistannoxanes, $\left[\mathrm{R}_{2}(\mathrm{X}) \mathrm{SnOSn}(\mathrm{X}) \mathrm{R}_{2}\right],\left(\mathrm{R}=\mathrm{CH}_{2} \mathrm{SiMe}_{3}\right), 3(\mathrm{X}=\mathrm{CI})$ and $5(\mathrm{X}=\mathrm{OH})$ (Eq. 5).<smiles>[R][R]([R])(Cl)O[Si]([R])([R])O[Si]([R])([R])O[Si]([R])([R])O[Si]([R])([R])Cl</smiles> 
The compounds 1 - 6 were also characterized by multinuclear NMR spectroscopy in solution and in the solid state, as well as by electrospray mass spectroscopy. However, these results will be published in a forthcoming paper [11].

\section{Acknowledgement}

We thank the Deutsche Forschungsgemeinschaft, the Fonds der chemischen Industrie, and the Australian Research Council for financial support.

\section{References}

[1] D. Seyferth, J. Amer. Chem. Soc. 79, (1957) 5881

[2] D. L. Alleston, A. G. Davies, M. Hancock, J. Chem. Soc. 1964, 5744.

[3] J. D. Murray, C. K. Chu, J. Chem. Soc. A 1971, 360.

[4] P. G. Harrison, M. J. Begley, K. C. Molloy, J. Organomet. Chem. 186 (1980) 213.

[5] H. Puff, E. Friedrichs, F. Visel, Z. Anorg. Allg. Chem. 477 (1981) 50.

[6] H. Puff, I. Bung, E. Friedrichs, A. Jansen, J. Organomet. Chem. 254 (1983) 23

[7] J. F. Vollano, R. O. Day, R. R. Holmes, Organometallics 3 (1984) 745.

[8] H. Puff, W. Schuh, R. Sievers, W. Wald, R. Zimmer, J. Organomet. Chem. 260 (1984) 271.

[9] R. Hämălăinen, U. Turpeinen, J. Organomet. Chem. 333 (1987) 323

[10] H. Puff, H. Hevendehl, K. Hofer, H. Reuter,W. Schuh, J. Organomet. Chem. 287 (1985) 163

[11] J. Beckmann, Henn, M., K. Jurkschat, M. Schürmann, D. Dakternieks, A. Duthie, Organometallics, manuscript submitted.

[12] K. Brandenburg, DIAMOND 2.1d, visualization software, 2000, Bonn, Germany. 
